\title{
Study of Population Activities in Establishing the Economic Welfare of Belawan Coastal Communities, North Sumatra
}

\author{
Riki Rahmad ${ }^{1}$, Fellix Rimba ${ }^{1}$, Mona Adria Wirda ${ }^{1}$ \\ Department of Geography Education, Faculty of Social Sciences, State University of Medan \\ J1. Willem Iskandar Pasar V 20221, Medan, Indonesia \\ Email: rikirahmad@unimed.c.id
}

\begin{abstract}
In general, coastal communities have cultural values that are oriented in harmony with nature, so technology utilizes the resources in adaptive technology with coastal conditions. The social life of coastal communities is not much different from the social life of other coastal communities in Indonesia, such as low education, seasonallydependent productivity, limited business capital, lack of means to support poor market mechanisms and the long transfer of technology and communications that result in coastal community income, Especially the processing fishermen become erratic. The purpose of this study is to determine the activity of the most dominant population around the coastal area of Bahari Village Medan Belawan, Indicator of community welfare, Effect of population activity on the welfare of the people of Bahari Village, Medan Belawan District. The location of research in Bahari Village Medan Belawan District. The timing of this research is started from the preparation of the proposal on 25 April, Implementation of research on May 1, 2017, and preparation of final report May 19, 2017. The methodology in this research is descriptive qualitative. Population in this research is head of environment and coastal community of Bahari village, Medan Belawan District. Some technical problems that hamper the welfare of fishers, among others, most are still traditional fishermen with socio-cultural characteristics that have not been conducive. Then, the fleet structure of capture that is still dominated by small/traditional businesses with weak scientific and technological skills. In addition to the low interest of schools in the surrounding coastal communities, the uncertainty of income received by fishermen, the indifference of most of the population will be the assistance provided by the government.
\end{abstract}

Keywords: Coastal, community, economic, Belawan

\section{Introduction}

Coastal is a meeting area between land and sea; on land covering the land part, either dry or submerged, still influenced by sea properties such as tides, sea breezes, and saltwater seepage; while towards the sea includes parts of the sea that are still affected by natural processes that occur on land such as sedimentation and freshwater flow, or caused by human activities on land such as deforestation and pollution (Wahyudin, 2011).

Based on the Decree of the Minister of Marine Affairs and Fisheries Number: KEP.10/MEN/2002 on General Guidelines for Integrated Coastal Management Plan, Coastal Zone is defined as a transitional region between interconnected terrestrial and marine ecosystems, where the sea is 12 miles from the coastline for the province and one third of the territory of the sea (provincial authority) to districts/municipalities and towards the border of the district / city administration (Widnyana, et al., 2016).

In general, coastal communities have cultural values that are oriented in harmony with nature so that technology utilizes the resources in adaptive technology with coastal conditions. The social life of the coastal community of the sub-district of Bahari, Medan Belawan district is not much different from the social life of other coastal communities in Indonesia, such as low education, season-dependent productivity, limited business capital, lack of supporting facilities for poor market mechanisms and communications that resulted in the income of coastal communities, especially the processing fishermen became uncertain.

The management of coastal areas is primarily linked to resources, however, requiring community participation. Ideas and solutions to environmental damage sometimes arise from local community initiatives themselves that are sometimes unthinkable in the scientific realm. This suggests that, in fact, communities often have good adaptability to their environment, although in a scientific perspective the environment may have been damaged (Rahmad, 2016).

The amount of marine potential is often not directly proportional to the level of welfare of fisherman. Fisherman are often regarded as one of the most identical groups of poverty. Most of them are traditional fisherman with limited capture capacity regarding technological mastery, capture method, and capital. The problem of poverty is also caused by the imbalance of fish resource utilization (Zebua, et al., 2017).

Since a long time, fisherman and coastal empowerment programs have not been explored proportionately. Utilization of marine natural resources is still done partially and less supported by appropriate technology so that 
the results obtained less than the maximum. The facts have an impact on the socio-economic life of coastal communities that are low, and even some live under poverty (Suyanto, 2007).

The more complex and competitive the processor fishermen are faced with the enormous challenges in the interconnection of fisherman's business with various aspects of the environment that affect it and competition in the utilization and use of available resources. For that, it is necessary to empower the processing fishermen for the improvement of welfare through the increase of income (Apridar \& Karim, 2011).

The purpose of this research is to raise the welfare of coastal communities in the view of the daily needs fulfillment sector and direct observation of field researcher and also expected later to be a channel information tool for the condition of coastal society and expected the government could assist to improve the development. The poverty rate of coastal communities in Indonesia is still very worrying at $32.4 \%$. In fact, Indonesia is the largest archipelago country that should be the sea of potential.

Some technical problems that hamper the welfare of fishers, among others, are mostly traditional fishermen with unfavorable socio-cultural characteristics (Satria, 2015). Then, the fleet structure of capture that is still dominated by small/traditional businesses with low scientific and technological skills. Of that number, only 4,487 units of ships are classified as modern, while 241,889 units of fishing boats are still a boat without a motor. Furthermore, there is an imbalance in fish utilization in $80 \%$ of the waters of the North Coast and shallow seas.

Geographically, coastal communities or fishermen are living, growing and developing communities in coastal areas, i.e., a transition region between land and sea areas. Sociologically, they have different social characteristics with other communities, because of the different characteristics of the resources they have. Welfare economically coastal communities rely heavily on fishery resources both capture fisheries in the sea and cultivation, which until now access is still open, so the environmental conditions of coastal and marine areas determine the sustainability of their socioeconomic conditions. Talking about fishing communities is almost certainly an issue which always appears are marginalized, poor and targeted by the exploitation of the ruler both economically and politically. The poverty that has always been a trademark for fishermen can in some cases be justified by several facts such as slum conditions, low levels of income and education, their vulnerability to social, political and economic changes, and their powerlessness to capitalist interventions, and the rulers who came. Besides, their poverty is also caused by the problem of coastal-marine ecosystem damage that has a serious impact on the depletion of fishery resources. Another issue that is not less important in the economic activities of fishers, primarily related to fishing operations is a matter of business capital to provide all the needs of fishing activities such as ship fuel, fishing equipment and so forth. For fishing communities, especially small fishermen or traditional fishers, the need for business capital, which can be accessed or that can be utilized at any time, is very high. This condition is a response to the large investment cost in the catching fishery sector, while the revenue is uncertain and the income level is varied. With the needs of household consumption to be met every day, fishers do not have sufficient funds savings if one day has to deal with the fact that the fishing facilities they use are damaged and require substantial repair costs. It is this limitation of cash holdings that encourage fishermen to trapped in complex accounts payable networks, especially to loan sharks or informal credit providers (Syatori, 2016).

Indonesia is a maritime country and listed as an archipelagic island with 17,508 islands surrounded by 81,000 $\mathrm{km}$ of coastline and 5.8 million square kilometers of ocean cover with an Exclusive Economic Zone of 2.78 million km2. About 60 million inhabitants are living in coastal areas and contribute about 22 percent of the national gross income. It is undeniable amid the enormous potential of the oceans that poverty is mostly located in fishermen's settlements. Indeed, many factors that cause the poverty of fishermen either naturally, structurally, and culturally.

Naturally, the sea is difficult to predict. High waves, strong winds or storms, and the destruction of nature makes the catch less and less. On the one hand, fishing communities have structural weaknesses. Weak capital capability, low management, weak institutions, under the grip of middlemen, and technological limitations.

Most of the 16 million families of fishermen in Indonesia are below the poverty line. Contrast with their role as a nation's protein hero. Cultural conditions can also encourage fishers increasingly plunge into the poverty gap. Great natural wealth often lulls us all. Dependence on marine resources results in resignation and this results in no increase in the quality of human resources.

Medan Belawan District is one of 21 sub-districts in Medan city, North Sumatera, Indonesia. Medan Belawan district borders Deli Serdang regency in the west, Deli Serdang regency in the east, Medan Marelan and Medan Labuhan in the south, and the Malacca Strait in the north.

Bahari village, Medan Belawan district is a settlement that is identical with the community of people who work as fishermen who have characteristics in the form of traditional societies with socioeconomic conditions, and educational background is relatively limited. The social conditions of fishing communities like this make them 
difficult to get the needs of settlements. It is also the case that encourages the emergence of fishermen settlements along the banks of rivers, in areas that are not supposed to be settled areas. The deplorable condition of the settlements with high building density and low quality of buildings is far from the standard of habitable settlements.

The background of choosing the location is, in general, many people who think that Medan city is an advanced metropolitan city. Whereas if viewed in detail, it turns out in one of the existing sub-district of Belawan, Medan Belawan district is located in the area of the ebb tide, so that when the ups and downs, most of their homes will be submerged. The problem of the residents of Bahari village especially regarding economic welfare can be said to be low, related to health factors, education, population activity and mindset of the people who are still low.

Based on the background that has been mentioned, the problems that can be identified are the activities of the people around the coastal area of Bahari Village, Medan Belawan District, indicator of community welfare, the ignorance of the community for the assistance of the government, the influence of the population activity on the welfare of the community.

Based on the identification of the above problems, the problem in this study is limited to the influence of population activity on the welfare of the people around the coast of Bahari village, Medan Belawan District. The purpose of this study is to determine the activity of the most dominant population around the coast of Bahari Village Belawan Medan, Indicator of community welfare and the influence of population activity on the welfare of the people of Bahari Village, Medan Belawan District.

Kusnadi, (2003) identifies the underlying causes of poverty in the fishing communities that form the basis of thinking as in Figure 1 below:

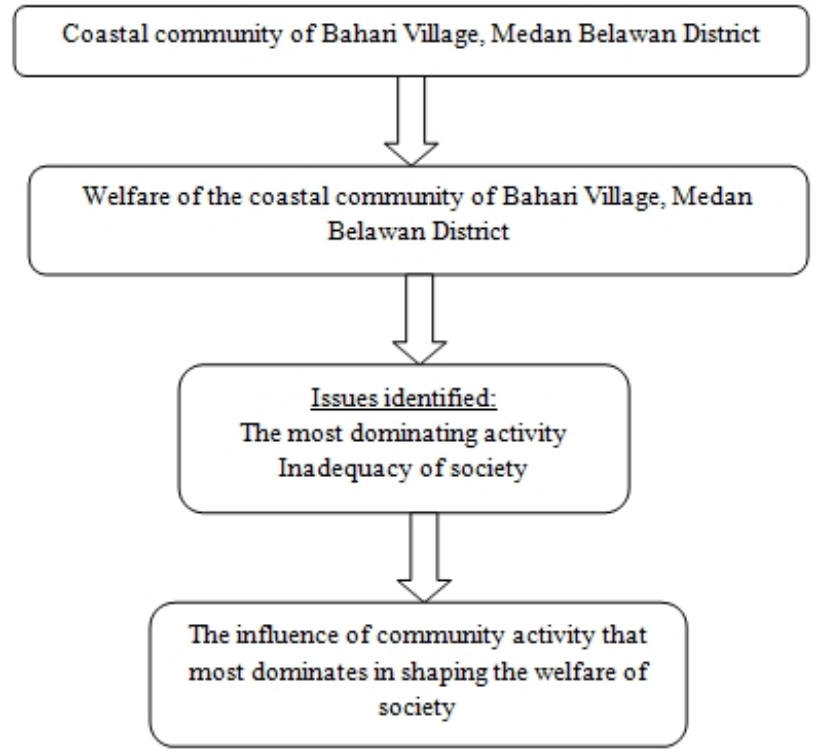

Figure 1. The Framework

\section{Research Method}

This research was conducted in the coastal area of Bahari Village, Medan Belawan District. As for the reason of this research location because want to know how real prosperity society around the coastal area of Bahari Village, Medan Belawan District. The timing of this study is to start with the preparation of the proposal on April 25, Implementation of the research on May 1, 2017, and the preparation of the final report of May 19, 2017. The population in this study is the head of the environment and the community around the coastal area of Bahari Village, Medan Belawan District. This study used a sample of one head of the environment and 30 people randomly around the coastal area of Bahari Village, Medan Belawan District. The research variable in this study is how to influence the activities of coastal communities of Bahari Village, District Belawan Medan. An operational definition is made to avoid misinterpretation of the variables studied. The observation technique used is an observation technique that focuses attention on an object by using the whole of the five senses. Through observation, it is expected to be mutually awakened false information that appears in the study. In this research, there is one observation stage. The things observed in this study cannot be separated from some of the issues 
from society. Observation is done by way of systematic recording of the symptoms studied and with consideration of observation and documentation. For the data required, appropriate recording and mapping data records are used. Interview Technique. Interview methods include the way one is assigned for a particular task purpose of trying to get a verbal description or opinion from the respondent by meeting face-to-face with the other person. Interview method is one way used by a researcher by way of meet directly and ask with the informant to try to get information orally related to the research problem. To obtain data that match the subject matter submitted during the interview, it is necessary to use the interview guide, which is in the form of questions related to the research. This is done with the aim of avoiding general answers. Questions are made based on points of a problem in research so that the interview can be done systematically. Interviews in the study were conducted in the form of structured interviews and free interviews. Structured interviews were conducted to obtain a picture of the identity and background of the informant. In the implementation of data collection in the field, researchers used in-depth interview techniques.

Documentation is one way of collecting data that produces essential records related to the problem to be studied, so that will be obtained complete data, valid and not based on the results of thought. Research conducted by using documentation technique aims to gather information not from the person as a resource, but researchers obtain information from various sources written or from documents that exist on informants in the form of reports. The document is a village profile that includes population, population composition, and livelihoods. Documentation carried out during research in coastal environments (conditions of economic activity of coastal communities).

Data Analysis Techniques. This research uses qualitative research methods with analytical, descriptive approach. The qualitative research method is used as a research procedure that produces descriptive data in the form of written or oral words of the people and behavior that can be observed. The goal is to describe the activities of the community to affect the welfare of the people in the coast of Belawan in-depth and thorough. To get the desired data, the researcher took to the field then inquired profoundly and observed it directly. Researchers searched data from various sources including BPS, BAPPEDA, and communities residing in the coastal area of Bahari village, Medan Belawan District.

\section{Result and Discussion}

\section{Physical condition}

Belawan I village is one of the sub-districts of Medan Belawan District, located at 1 meter above sea level, with an average temperature of $32^{\circ} \mathrm{C}$, tropical climate influenced by rainy season with an average rainfall of 2600 mm per year.

The distance from the farthest village to the central Government District $\pm 1 \mathrm{Km}$ with travel time \pm 0.2 hours, while the distance to Medan City $\pm 26 \mathrm{~km}$ with travel time \pm 1 hour. The boundaries Belawan I Village as follows:

- North is bordered by Hamparan Perak

- South is bordered by Belawan II

- West is bordered by Belawan Bahagia village

- East is bordered by Malacca Strait

\section{Non-Physical Condition}

The population is the necessary capital of development of an area by its potential regarding both quantity and quality. This potential will be a major force in managing and utilizing its natural resources that will ultimately speed up the development process.

The number of residents Belawan I Village is 21,783 people with the number of household heads as many as 3666 households.

Population composition according to age is necessary to know because based on the composition can be identified the number of productive age population so that it can be recognized the size of the dependence.

The livelihood of a region's population tends to vary. Many factors influence such as natural resources, skills, and education and local culture. Similarly in Belawan I Village, to know the percentage of livelihood variation can be seen in Table 1 and 2 below: 
Table 1. Population Composition Based on Livelihood Sub Sector Fisheries At Belawan I, Medan Belawan district, 2006

\begin{tabular}{|c|c|c|}
\hline & Status & Number (people) \\
\hline 1 & Owner of boat & - \\
\hline 2 & Owner of the ship & 60 \\
\hline 3 & Owner/grower of seaweed & - \\
\hline 4 & Owner of the pool & - \\
\hline 5 & Owner of the pond & - \\
\hline 6 & Owner of cageculture & - \\
\hline 7 & fisheries/fishermen & 142 \\
\hline \multirow[t]{2}{*}{8} & Etc & \\
\hline & Amount & 202 \\
\hline
\end{tabular}

Source: Profile of Bahari village, Medan Belawan District, 2006

Table 2. Population Composition Based on Livelihoods of Agriculture Sub-sector Food Plants In Belawan I Village, Medan Belawan District, 2006

\begin{tabular}{|l|l|c|}
\hline No & \multicolumn{1}{|c|}{ Status } & Number (people) \\
\hline 1 & Owner of paddy fields & 8 \\
\hline 2 & owner of moor & 10 \\
\hline 3 & Tenant & - \\
\hline 4 & Peasant farmers & - \\
\hline 5 & Farm workers Amount & - \\
\hline & \multicolumn{1}{|c|}{ Ams } \\
\hline
\end{tabular}

Source: Profile of Bahari village, Medan Belawan District, 2006

\section{Community Welfare Indicators}

Several studies have found that community economic independence is strongly influenced by factors inside and outside the community. In the long run, both of the above factors are more on the historical approach, namely that the resources owned given. Such resources exist and possessed in such a way that to change and develop is dependent on how they managed. In addition, external factors will assist in accommodating to achieve a high achievement. Factors from within (endowment factor) often already exist and owned in accordance with the provisions (a) The character of the environment, can be seen from the daily activities of the surrounding community; (b) Education, viewed from the point of view of the many desires of children dropping out of school while the available schools according to population capacity; (c) Health, viewed from the eyes of the number of health centers; (d) Income, in terms of livelihood aspect and income received whether it can meet daily needs; (e) Awareness wants to change, the amount of aid provided by the government to communities around the coast but from the community itself less responsive to the assistance provided by the government, both in the form of insurance and other cards.

According to Genpenus (2016), the indicators of community welfare are divided into three, namely (a) Number and distribution of income, (b) Education increasingly easy to reach, (c) Improved and equitable health quality.

While the factor outside (exogenous) is more complementary, for example, aspects of technology, markets and so forth. Community independence is also influenced by the resource potential, resource utilization, and conservation so that applied research is fundamental. In the area of research can be put forward socio-economic conditions as a potential (resources) there is very adequate.

Based on field observations in the coastal areas, some results related to coastal life are as follows:

Population activity. Based on physiographic in Belawan, almost $90 \%$ of the people's livelihoods around the coast of Belawan are fishermen and the remaining about $10 \%$ are livelihoods as traders and becak drivers.

Education. Based on interviews conducted by the Chairman of the neighborhood Belawan Lorong Melati area can conclude that the average children of the area no one up to the level of high school or college, if any, even then dropped out of school. This is because the coastal children are more concerned with sustaining their lives by helping parents to go to sea instead of continuing their studies. Regarding the condition of the school in the area, the head of the environment said that the condition of the school did not cause the local coastal children do not want to go to school anymore, instead the head of the environment said that the condition of coastal children's schools is very supportive of the teaching and learning process in the classroom. It's just a lack of motivation or 
awareness of the local community about the importance of education. Government efforts to improve the quality of education in coastal areas can see from the existence of Smart Indonesian Card already owned by some residents, but as has been said at the beginning that the lack of motivation or awareness of the local community about the importance of education, in other words, is still secondary education.

Economics. Based on interview data conducted in Belawan, Lorong Melati, it can be concluded that the average income earned by the head is uncertain depending on the catch. The fishermen go to sea for a week, sometimes more than that and with uncertain income. We went to other respondents to get the accuracy of the data. We asked about their income and still with the same answer, went to sea with the day and uncertain income.

Health. Based on the interviews we conducted in Belawan area, Lorong Melati can be concluded that not all fishermen in this environment have a marine safety insurance card. This is because, at the time of the socialization of this card, the local community is still indifferent or in other words still less trust. The environmental health of this area is very concern, and this is also due to the lack of awareness of local communities in maintaining cleanliness. The average house in this area is a house on stilts. Under the house, there is a lot of scattered rubbish. Even when the tide is rising, it is possible that every house in this area will be drowned and the garbage will go into the house. The height of water entering the house can be estimated about half a meter. Based on an interview conducted by the head of the Belawan neighborhood environment, Lorong Melati about the disease that is often experienced by the community here with the answer there is no dangerous disease. Meanwhile, according to some respondents and head of the environment, for the health center itself, there is only one medical clinic.

Weather. Based on interviews conducted by the Head of the Environment and the fishermen in the Belawan region, Lorong Melati can be concluded that the weather influences the activity of the population here. Explanation from the Head of Environment and the people around the weather is an essential element to carry out the activities of the sea, when bad weather the fishermen do not go to sea, and if the good weather they go to sea, it clearly affects the income received.

Public awareness. There has been government assistance to coastal communities to curb poverty, but government assistance has not responded well. The attitude of the community is so indifferent that the distribution of insurance cards and other aid from the government has not been evenly distributed.

\section{Conclusion}

Based on the discussion in the previous chapter, it can be concluded as follows:

1. $90 \%$ of the livelihoods of Belawan coastal communities are fishermen, and the remaining $10 \%$ are livelihoods as traders and pedicab drivers.

2. The average children of the area no one up to the level of high school or college, if any it dropped out of school. This arises because these coastal children are more concerned with sustaining their lives by helping parents to go out to sea than the school.

3. The average income generated by each head is not necessarily dependent on the catch.

4. Not all fishermen in this environment have a marine safety insurance card.

5. Weather is an essential element for fishing activities, when bad weather the fishermen do not go to sea, and if the weather is good, they go to sea this is clear.

6. The attitude of the community is indifferent, so the distribution of insurance cards and other aid from the distribution government has not been evenly distributed.

\section{References}

Apridar, M., \& Karim, S. (2011). Ekonomi Kelautan dan Pesisir. Graha Ilmu, Yogyakarta. Genpenus. (2016). Retrieved May 17, 2017, from Genpenus: http://genpenus.id/indikator-kesejahteraan-sosial/ Kusnadi. 2003. Akar Kemiskinan Nelayan. Yogyakarta: LkiS.

Rahmad, R. (2016). IDENTIFIKASI PERMASALAHAN DAN REKOMENDASI STRATEGI PENGELOLAAN PESISIR PURWOREJO-JAWA TENGAH (Studi Kasus: Areal Bekas Penambangan PT ANTAM). JURNAL GEOGRAFI, 8(1). 
Rahmad, R., Panjaitan, B. R., Silaban, D., \& Muladi, M. R. (2017). The Impact of Rob Flood and Community Adaptation in Coastal Area of Medan Belawan, Medan City, North Sumatra, Indonesia. JURNAL GEOGRAFI, 9(2), 117-124.

Satria, A. (2015). Pengantar sosiologi masyarakat pesisir.Yayasan Pustaka Obor Indonesia.

Suyanto, I. (2007). Studi Implementasi Program Pemberdayaan Masyarakat Pesisir (PEMP) Studi Kasus Masyarakat Pesisir Kelurahan Tanjungmas Kota Semarang (Doctoral dissertation, Faculty of Social And Political Science).

Syatori, A. (2016). EKOLOGI POLITIK MASYARAKAT PESISIR (Analisis Sosiologis Kehidupan Sosialekonomi dan Keagamaan Masyarakat Nelayan Desa Citemu Cirebon). Holistik, 15(2).

Wahyudin, Y. (2011). Karakteristik sumberdaya pesisir dan laut kawasan Teluk Palabuhanratu, Kabupaten Sukabumi, Jawa Barat. Bonorowo Wetlands, 1(01), 19-32.

Widnyana, I. M. D., Astiti, N. W. S., \&Handayani, M. T. (2016).Perilaku Anggota Kelompok Nelayan Wanasari dalam Menjaga Kelestarian Hutan Mangrove di Kelurahan Tuban, Kecamatan Kuta, Kabupaten Badung. E-Journal Agribisnis dan Agrowisata (Journal of Agribusiness and Agritourism), 5(1).

Zebua, Y., Wildani, P. K., Lasefa, A., \& Rahmad, R. (2017). FAKTOR PENYEBAB RENDAHNYA TINGKAT KESEJAHTERAAN NELAYAN PESISIR PANTAI SRI MERSING DESA KUALA LAMA KABUPATEN SERDANG BEDAGAI SUMATERA UTARA. JURNAL GEOGRAFI, 9(1), 88-98. 